\title{
PENGUATAN DESA WISATA SIKASUR DI ERA NEW NORMAL
}

\author{
${ }^{1 *}$ Wenefrida Ardhian Ayu Hardiani, ${ }^{2}$ Julian Adriani Putri, ${ }^{3}$ Ray Octafian, \\ ${ }^{4}$ YR Satato, ${ }^{5}$ Heni Krisnatalia \\ Sekolah Tinggi Ilmu Ekonomi Pariwisata, Semarang, Indonesia \\ Email : *wenefrida.ayu@gmail.com, andrianijulian@gmail.com, \\ rayoctafian@stiepari.ac.id,yuniartosatato@stiepari.ac.id, \\ henikrisnatalia@stiepari.ac.id
}

Manuskrip: Juni -2021; Ditinjau: Juni -2021; Diterima: Juli -2021;
Online: Juli-2021; Diterbitkan: Juli-2021

\begin{abstract}
ABSTRAK
Pandemi covid- 19 yang terjadi di awal tahun 2020 memiliki dampak yang cukup besar terutama di sektor pariwisata. Desa Wisata termasuk salah satu sektor dalam pariwisata yang terdampak pandemi covid-19. Perubahan perilaku memaksa semua lapisan masyarakat merubah tatanan hidup atau yang disebut era new normal.

Tim Pengabdian Masyarakat dari STIEPARI Semarang berupaya melakukan pendampingan di Desa Wisata Sikasur ini. Diharapkan dari pendampingan dari tim STIEPARI Semarang dapat semakin menguatkan eksistensi dan meningkatkan kualitas Desa Wisata Sikasur di Kabupaten Pemalang, baik itu dalam mutu SDM, produk yang ditawarkan, pengaturan dan pengelolaan manajemen desa wisata termasuk di dalamnya pengelolaan homestay. Serta yang paling utama adalah bagaimana penerapan CHS di Desa Wisata Sikasur, sehingga penerapan protokol kesehatan di era new normal ini dapat dilakukan dengan baik.

Dalam kegiatan pengabdian ini dilakukan antara lain survey lokasi, Forum Grup Discussion (FGD), dan sosialisasi. Hasil dari kegiatan ini diharapkan dapat membuat Desa Wisata Sikasur mulai beradaptasi dan berkembang di era new normal ini.
\end{abstract}

\section{Kata Kunci: Desa Wisata, CHS, New Normal}

\section{PENDAHULUAN}

Sebagaimana kita ketahui bersama bahwa Pandemi covid - 19 berdampak terhadap beberapa negara yang ada di dunia, termasuk Indonesia. Beberapa sektor yang dikembangkan di Indonesia untuk menumbuhkan perekonomian merasakan dampak dari pandemi covid-19, salah satunya adalah pariwisata. Di dalam sektor Pariwisata sejak pandemi mengalami penurunan wisatawan mancanegara seiring dengan pengurangan penerbangan internasional, wisatawan nusantara juga menurun dan mungkin akan semakin turun mengingat beberapa kebijakan yang diterapkan oleh pemerintah (Mohamad D. Revindo, Syahda Sabrina, 2020). 
Kebijakan yang diambil dan diterapkan oleh pemerintah bertujuan untu meminimalkan kasus penyebaran covid-19, pembatasan-pembatasan kegiatan pariwisata memaksa pariwisata Indonesia untuk berhenti secara total meski hanya sementara waktu dengan kurun waktu yang belum diketahui. Pemberhentian kegiatan pariwisata sementara waktu ini berimbas ke beberapa industri yang berkaitan dengan pariwisata, beberapa industri antara lain yaitu perhotelan, tranportasi, usaha mikro kecil dan menengah (UMKM) yang menghasilkan cindera mata dan kuliner, restoran, biro perjalanan wisata dan beberapa industri lainnya (Sutrisnawati et al., 2020). Pemberhentian kegiatan pariwisata dirasakan oleh desa wisata yang ada, dalam sebuah survey yang dilakukan oleh desa wisata institute (2020) dengan 97 desa wisata yang ada di seluruh Indonesia memberikan hasil bahwa terdapat 92,8 persen atau berkisar 90 desa wisata yang terdampak pandemi covid-19 (Fitriana et al., 2020).

Jika diterapkan pemberhentian sementara kegiatan pariwisata dalam waktu yang lama tentu akan memberikan dampak yang begitu besar bagi pariwisata itu sendiri, untuk itu pemerintah menghimbau masyarakat untuk merubah pola tatanan hidup atau dikenal dengan istilah new normal. Pola tatanan hidup ini antara lain menggunakan masker, menjaga jarak dan mencuci tangan atau yang disebu dengan 3M, selain new normal pemerintah juga mengeluarkan ketentuan CHSE (Cleanliness, Health, Safety, dan Environment) bagi setiap pelayan pariwisata dengan harapan pariwisata mulai bangkit dan penyebaran virus dapat ditekan. CHSE didasari Keputusan Menteri Kesehatan mengenai Protokel kesehatan (Prokes) ditempat dan fasilitas umum dalam rangka pencegahan penyebaran virus covid-19, bahkan oleh pemerintah CHSE diberikan sertifikasi khusus yang artinya setiap tempat yang sudah memiliki lisense CHSE tersebut sudah terjamin protokol kesehatannya, sertifikasi ini tidak diwajibkan tetapi diharapkan untuk diterapkan dengan tujuan kegiatan pariwisata bisa berjalan kembali sesuai Prokes dan pariwisata mulai bangkit. Kuncinya adalah cleanliness, health, safety, industri pariwisata harus membangun kepercayaan orang untuk berwisata ditengah pandemi covid-19 (Rosanti et al., 2020)

Kemandirian desa wisata memang diuji dalam masa pandemi ini. Desa wisata yang memiliki banyak pemasukan dari kegiatan wisata kini harus mengatur ulang strategi untuk tetap bertahan dengan kemandirian yang dibentuk. Salah satu contoh Desa yang tetap mandiri selama masa pandemi ini adalah Desa Sikasur di Kabupaten Pemalang. Masa pandemi juga digunakan masyarakat untuk memperbaiki fasilitas-fasilitas pendukung di destinasi wisata dan peningkatan kapasitas SDM pengelola desa wisata. Dalam mempertahankan eksistensi Desa Wisata ini dalam era New Normal Desa Sikasur perlu pendampingan yang nantinya 
diharapkan akan semakin menguatkan dan meningkatkan eksistensi Desa Sikasur ini. Berdasarkan latar belakang yang telah dijelaskan di atas, tim Pengabdian Masyarakat dari Sekolah Tinggi Ilmu Ekonomi Pariwisata Indonesia (STIEPARI) Semarang berupaya melakukan pendampingan di Desa Wisata Sikasur ini, materimateri terkait penguatan desa wisata di era new normal yang nantinya akan disampaikan kepada masyarakat yang ada di Desa Sikasur, seperti : Sapta Pesona, Sadar Wisata, CHS (Cleanliness, Health and Safety), Manajemen Pelayanan dan Service Excellent. Diharapkan dari materi yang disampaikan dari tim STIEPARI Semarang dapat semakin menguatkan eksistensi dan meningkatkan kualitas Desa Wisata Sikasur di Kabupaten Pemalang, baik itu dalam mutu SDM, produk yang ditawarkan, pengaturan dan pengelolaan manajemen desa wisata termasuk di dalamnya pengelolaan homestay. Serta yang paling utama adalah bagaimana penerapan CHS di Desa Wisata Sikasur, sehingga penerapan protokol kesehatan di era new normal ini dapat dilakukan dengan baik, ketika CHS sudah diterapkan oleh Desa wisata ini hal ini akan mempengaruhi keinginan pengunjung untuk mengunjungi desa wisata ini, karena pengunjung merasa keselamatan dan kesehatanya terjamin di tengah pandemi ini.

\section{METODE PELAKSANAAN}

Metode pelaksanaan pengabdian ini berupa kegiatan - kegiatan seperti survey lokasi, Sosialisasi, dan Focus grup discussion (FGD). Survey lokasi ini dilakukan dengan melakukan observasi di lingkungan desa wisata mengenai tingkat sadar wisata, pengelolaan homestay, tempat wisata, CHSE. Melihat apakah sudah dilakukan penerapan yang benar tentang pengelolaan desa wisata khusunya di Desa Sikasur.

Focus grup discussion (FGD) diisini dengan tanya jawab pada pengelola desa wisata. Disini para pengelola desa wisata sikasur seperti pengelola homestay, pengelola tempat wisata, pengelola tempat oleh - oleh dipersilahkan untuk memberikan pertanyaan dan sharing serta diskusi mengenai masalah di tempat masing - masing.

Sosialisasi ini dilakukan untuk memberikan wawasan kepada para pengurus desa wisata dalam hal ini desa wisata Sikasur yang berada di Kabupaten Pemalang, Jawa Tengah. Wawasan diberikan oleh pakar - pakar yang ahli di bidangnya tentang pengelolaan desa wisata di era new normal dan secara khusus mengenai CHSE. 


\section{HASIL DAN PEMBAHASAN}

Kegiatan pendampingan desa wisata ini dilakukan dalam 3 kali kunjungan pada bulan oktober - Desember 2020. Pada kunjungan pertama, dilakukan survey lokasi untuk melihat bagaimana kondisi di Desa Wisata Sikasur. Kunjungan pertama ini untuk mengetahui bagaimana kondisi lingkungan di Desa Wisata Sikasur. Apakah penerapan CHS (Cleanliness, Healthy, and Safety) sudah berjalan dengan baik, di Desa Wisata Sikasur khususnya di era new normal yang menuntut suatu kebiasaan yang baru. Pada saat melakukan pengabdian masyarakat dilakukan penerapan protocol kesehatan 3M yaitu Mencuci tangan, Memakai masker, dan Menjaga jarak.

Adapun hasil dari survei mengatakan bahwasanya selama ini mereka hanya menerapkan 3M, karena banyak tamu yang hanya datang lalu pulang, penerapan CHS di homestay belum ada karena mereka belum mengetahui apa itu CHS, perlu banyak perbaikan di beberapa tempat atau fasilitas yang ada

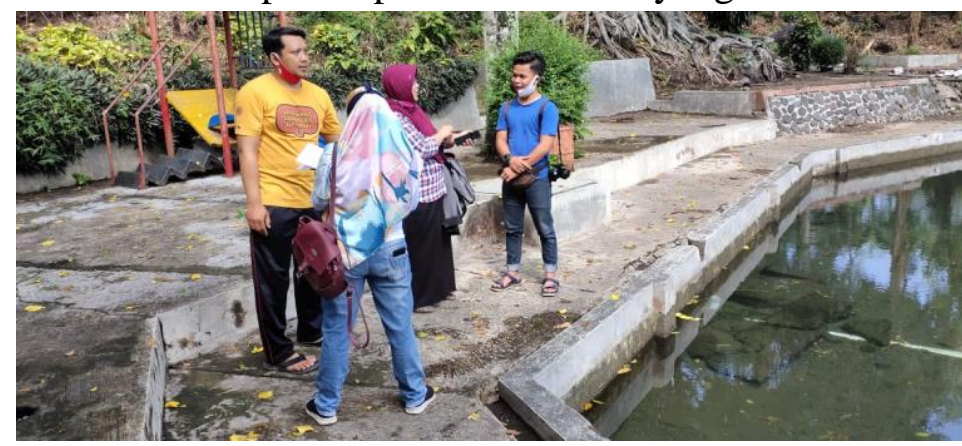

Gambar 1. Kegiatan Survey Lokasi di salah satu tempat pariwisata di Desa Sikasur

Kegiatan kedua adalah Focus Grup Discussion (FGD) yang mana dalam kegiatan ini peserta FGD melakukan sharing tentang permasalan yang ada di desa wisata sikasur, kekurangan-kekurangan yang harus di perbaiki untuk kemudian di bahas di kegiatan yang ketiga, adapun kegiatan FGD yang sedang berlangsung seperti pada gambar berikut :

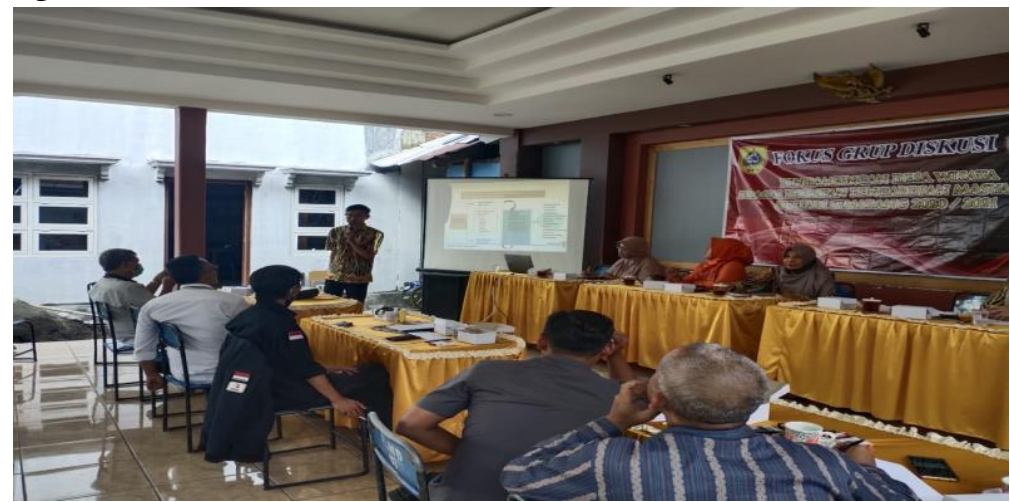

Gambar 2. Kegiatan FGD di Desa Wisata Sikasur 


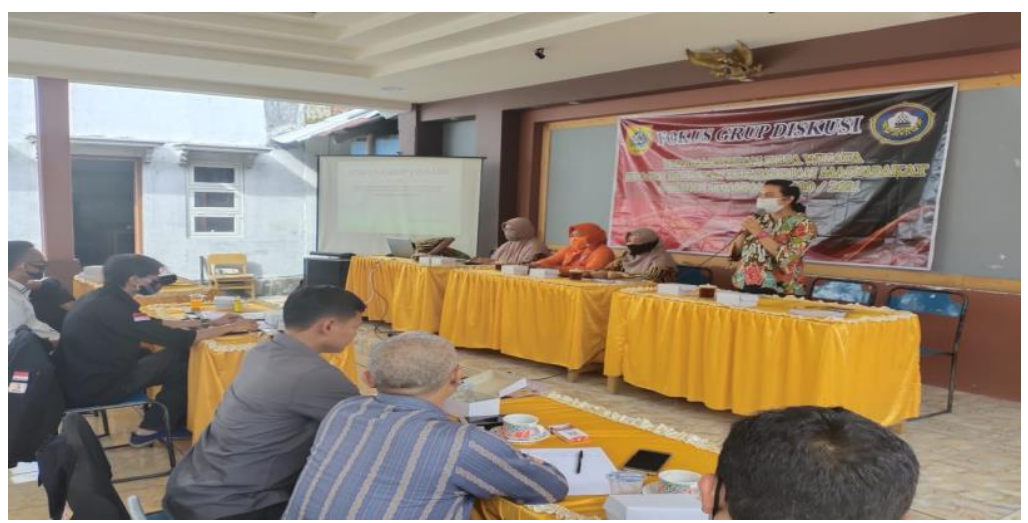

Gambar 3. Forum Grup Discussion sedang berjalan

Kegiatan ketiga adalah sosialisasi, dimana dalam kegiatan ini ada beberapa materi yang di sampaikan antara lain Sapta Pesona, Sadar Wisata, CHS (Cleanliness, Health and Safety) dan beberapa materi yang berkaitan dengan desa wisata. Adapun kegiatan FGD yang sedang berlangsung seperti pada gambar berikut :

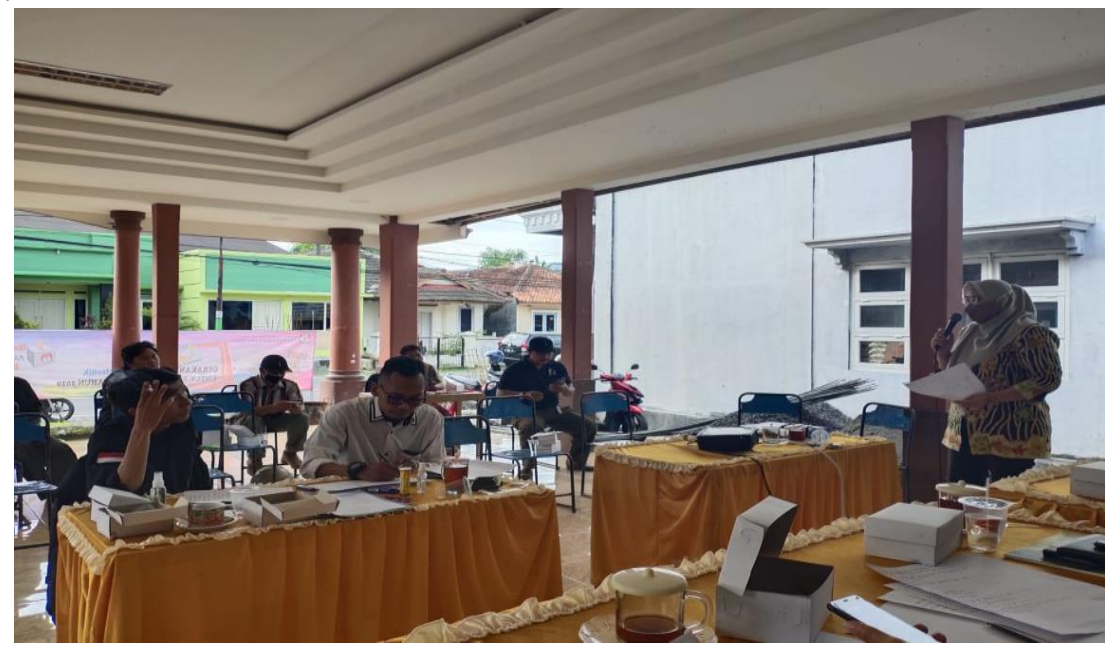

Gambar 4. Kegiatan Sosialisasi

\section{KESIMPULAN DAN SARAN}

Kesimpulan dari kegiatan pengabdian masyarakat ini adalah masih perlu adanya pendampingan lebih lanjut, meningkatkan wawasan terkait new normal dan CHSE untuk pengelola desa wisata terutama di Desa Wisata Sikasur. Wawasan dan kompentensi yang diberikan terutama dalam penerapkan CHS (Cleanliness, Healthy, Safety and Environment) homestay, pengelolaan manajemen pelayanan, sadar wisata, sapta pesona, dan bagaimana melakukan pelayanan yang prima di era new normal ini. 


\section{UCAPAN TERIMA KASIH}

Tim pengabdian masyarakat mengucapkan terima kasih kepada Dinas Pariwisata dan Olah Raga Kabupaten Pemalang, kepala desa Sikasur atas kerjasama dan antusiasme yang baik sehingga pelaksanaan kegiatan pengabdian dapat berjalan dengan baik. Kami mengucapkan terima kasih kepada STIEPARI Semarang yang selalu mendukung sehingga kegiatan pengabdian masyarakat berjalan di Desa Wisata Sikasur dapat berjalan dengan lancar.

\section{DAFTAR PUSTAKA}

Almuttaqi, A. I. (2020). The Chaotic Response To Covid-19 In Indonesia. The Habibie Center Insights,1(13),1-7. http://habibiecenter.or.id/img/publication/66f28c42de71fefe1c6fcdee37a5c1 a6.pdf

Bascha, U. F., Reindrawati, D. Y., Witaningrum, A. M., \& Dwi Setiani Sumar. (2020). Dampak Pandemi COVID-19 Terhadap Minat Masyarakat dalam Berwisata dan Sosialisasi Penerapan Protokol New Normal Saat Berwisata. Jurnal Abdidas, 1(3), 119-124.

Devy Dwi Fajri. (2020). Abdimas Pariwisata. 1(1), 26-32.

Djausal, G. P., Larasati, A., \& Muflihah, L. (2020). Strategi Pariwisata Ekologis Dalam Tantangan Masa Pandemik Covid-19. Jurnal Perspektif Bisnis, 3(1), 57-61. https://doi.org/10.23960/jpb.v3i1.15

EUROPEAN COMMISSION. (2020). COVID-19: EU Guidance for the progressive resumption of tourism services and for health protocols in hospitality establishments. $E u$. file:///C:/Users/User/Downloads/fvm939e.pdf

Fitriana, R., Simanjuntak, D., Dewanti, R., \& Author, C. (2020). Pembekalan Materi CHSE (Cleanliness, Health, Safety and Environmental Sustainability) dalam Training of Trainers Akademisi Pendamping Desa Wisata History Article. CARADDE: Jurnal Pengabdian Kepada Masyarakat, 3(1), 138-145. https://journal.ilininstitute.com/index.php/caradde

kemenparekraf. (2020). Panduan Pelaksanaan dan Kelestarian Lingkungan di Penyelenggaraan Kegiatan (Event ). 2019(September).

Kurniawati, K. R. A., Negara, H. R. P., Ahmad, Santosa, F. H., Bahri, S., \& Parihin. (2020). Pendampingan Gerakan Hidup Bersih dan Sehat Di Era New Normal. JMM (Jurnal Masyarakat Mandiri), 4(6), 1262-1272.

Mohamad D. Revindo, Syahda Sabrina, M. S. (2020). Dampak Pandemi Covid-19 terhadap Pariwisata Indonesia: Tantangan, Outlook dan Respon Kebijakan. Pusat Kajian Iklim Usaha Dan GVC - LPEM FEB UI, April.

Pratiwi, R., Rama, R., Sulistiyanti, N. (2020). Building the Trust for The Tourism Destination Resiliency in New Normal Society (The Role Of Wellness Tourism System). Jurnal IKRA-ITH Humaniora , 5(1), 140-148.

Puspitasari, D., Ahimsa-Putra, H. S., \& Wijono, D. (2019). Persepsi Dan Pengelolaan Homestay Di Desa Wisata Wukirsari, Bantul. Jurnal Kawistara, 9(1), 1. https://doi.org/10.22146/kawistara.37314 
Rosanti, Y., Putra, M. D. T., \& Irawan. (2020). Tantangan dan Strategi Customer Relationship Marketing dengan Prinsip Cleanliness, Health, and Safety ( CHS ) dalam Upaya Pemuliha Ekonomi di Kawasan Wisata Samosir sebagai pengembang citra namun mampu memasarkan produk kepada publik . Customer. 1177, 1-12.

Sanjiwani, P. K. (2020). Dampak Pandemi Covid-19 Terhadap Citra Destinasi Wisata (Kajian Di Kabupaten Badung ) Pemikiran Kepariwisataan i. August. Setyaningrum, K., Octafian, R., \& Maria, A. D. (2020). Penerapan Cleanliness, Health, Safety and Environment ( Chse ) Homestay Untuk Keselamatan. 1(1), $18-22$.

Sugihamretha, I. D. G. (2020). Respon Kebijakan: Mitigasi Dampak Wabah Covid19 Pada Sektor Pariwisata. Jurnal Perencanaan Pembangunan: The Indonesian Journal of Development Planning, 4(2), 191-206. https://doi.org/10.36574/jpp.v4i2.113

Suni, N. S. P. (2020). Kesiapsiagaan Indonesia Menghadapi Potensi Penyebaran Corona. Pusat Penelitian Badan Keahlian DPR RI, XII(3), 14-18. https://berkas.dpr.go.id/puslit/files/info_singkat/Info Singkat-XII-3-I-P3DIFebruari-2020-1957.pdf

Sutrisnawati, N. K., Gusti, N., Nyoman, A., \& Ardiasa, I. K. (2020). Upaya Pemulihan Sektor Pariwisata Di Tengah Pandemi Covid 19. Jurnal Kajian Dan Terapan Pariwisata, 1(1), 39-57.

Wedatama, A. A., \& Mardiansjah, F. H. (2018). Pengembangan Homestay Berbasis Masyarakat Pada Kampung Homestay Borobudur. Jurnal Pengembangan Kota, 6(2), 135. https://doi.org/10.14710/jpk.6.2.135-143 